\title{
An emended and amplified description of Pecopteris apicalis Knight, a fern morphospecies of mid-Stephanian age from NW Spain
}

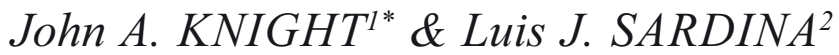 \\ ${ }^{1}$ Centro Paleobotánico, Real Jardín Botánico de Córdoba, Avenida de Linneo, s/n, 14004 Córdoba, Spain; jaknightuk@btinternet.com \\ ${ }^{2} \mathrm{C} /$ Bartolomé de Carranza, no 42, 4 Izda, 31008 Pamplona, Navarra, Spain; luisjsardi@gmail.com \\ * Corresponding author
}

Knight, J.A. \& Sardina, L.J. 2016. An emended and amplified description of Pecopteris apicalis Knight, a fern morphospecies of mid-Stephanian age from NW Spain. [Descripción ampliada y enmendada de Pecopteris apicalis Knight, morfoespecie de helecho del Estefaniense medio del NO de España]. Spanish Journal of Palaeontology, 31 (1), 95-114.

Manuscript received 05 April 2016

Manuscript accepted 22 April 2016

(C) Sociedad Española de Paleontología ISSN 2255-0550

\begin{abstract}
Extensive adpression material of the fern morphospecies Pecopteris apicalis Knight has been collected from overburden from opencast mining in the Peragido-Vallejo area of the Barruelo Coalfield, close to the collection site of the holotype of the species. This has permitted a more detailed description of key characteristics than was previously possible and an emended diagnosis. The large frond fragments demonstrate large pinnae of antepenultimate order, length in excess of $0.4 \mathrm{~m}$, with apparent attachment to a very robust petiole in a tripinnate frond structure. The extensive material permits the variation in the terminal area of penultimate pinnae to be documented. Other diagnostic features of the species confirmed in this wide range of material cover the dimensions, acuminate shape, and terminal of last order pinnae, the range of dimensions and shape of pinnules and the characteristic consistently bifurcate venation. Fertile organs have been identified only on one specimen collected from another opencast working in the Barruelo Coalfield, at a lower level in the same stratigraphic unit. Although indistinct, the fertile organs comprise two rows of small circular sori on either side of the mid-vein, reminiscent of the genus Asterotheca Presl, although the material does not permit reliable identification. Discussion of the possible systematic relationships of this
\end{abstract}

\section{RESUMEN}

Una gran cantidad de adpresiones de la morfoespecie de helecho Pecopteris apicalis Knight ha sido recogida de las escombreras de las minas a cielo abierto del área de PeragidoVallejo, cuenca minera de Barruelo, próxima al lugar de procedencia del holotipo de la especie. Esto ha permitido hacer una descripción más detallada de la que se pudo hacer inicialmente y enmendar la diagnosis. Los grandes fragmentos de fronde muestran grandes pinnas de antepenúltimo orden de más de $0.4 \mathrm{~m}$ de longitud, aparentemente unidas a un peciolo robusto en una fronde tripinnada. La gran cantidad de material permite documentar la variabilidad de la parte apical de las pinnas de penúltimo orden. Otros rasgos diagnósticos de la especie que se han confirmado con esta amplia variedad de material incluyen las dimensiones, la forma acuminada y la forma de la terminal de las pinnas de último orden, las dimensiones y la forma de la pínnulas, así como la característica nerviación consistentemente bifurcada. Los órganos fértiles han sido identificados en un solo ejemplar recogido en otro cielo abierto de la misma cuenca de Barruelo, en un nivel inferior pero dentro de la misma unidad estratigráfica. Aunque poco definidos, los órganos fértiles se componen de dos filas de soros circulares situados a cada lado del nervio central, que recuerdan al género Asterotheca 
species suggests the closest affiliation is with the cyatheoid group of pecopterid marattialian species. The PeragidoVallejo material occurs within a low diversity flora which has undergone minimal transport from its site of growth, interpreted as in an interdistributary back-swamp area on a near-coastal alluvial plain.

Keywords: Pecopteris apicalis, emended diagnosis, systematic relationships, Barruelian, NW Spain.

\section{INTRODUCTION}

Fragmentary vegetative pecopterid foliage attributed to Pecopteris apicalis Knight has been recorded widely as adpressions in coal-bearing successions of Barruelian to Stephanian B (sensu stricto) age in northern and central Spain (Castro-Martínez, 2005; Wagner \& Álvarez-Vázquez, 2010). This species is one of a number of form-species with superficially similar characteristics with respect to pinna and pinnule morphology and venation, in which specific identification is complicated by the number of species erected on only fragmentary material in which the range of variation within the frond is largely unknown. However, the formal description (Knight, 1985) of P. apicalis was based on a relatively large collection of material from two coalfields, the Barruelo and Sabero coalfields, respectively, from horizons of Barruelian age and Barruelian extending through Saberian age, in the context of Knight \& Wagner (2014). In consequence, the original description was able to encompass a relatively comprehensive range of variation in diagnostic characteristics, to the extent that this species has proved readily identifiable in collections from the midStephanian age coalfields of northern Spain (see lists in Wagner \& Álvarez-Vázquez, 2010).

Recently one of the authors of this paper (L-JS) has made an extensive collection of material of $P$. apicalis from one well-constrained short succession in the Barruelo Coalfield (province of Palencia, N. Spain), in which large slabs have permitted that a significantly more detailed description can encompass the range of variation within this one form-species. While the presently described material does not contribute unequivocal evidence of fertile organs, the documentation of the wide range of morphology is here considered an important step to understanding the range of variation in this one species and the preservation and potential variability of fern foliage in late Pennsylvanian strata.

A large amount of well-preserved material has been collected from the area of a disused opencast coal
Presl, pero el material es insuficiente para una identificación fiable. La discusión de las posibles relaciones sistemáticas de la especie sugiere que la relación más estrecha puede ser con el grupo cyatheoide de pecopteridos marattiales. El material de Peragido-Vallejo contiene una baja diversidad de especies que experimentaron un transporte mínimo desde el lugar de crecimiento; se interpreta como un área pantanosa al resguardo de los canales distributarios de una llanura aluvial costera.

Palabras clave: Pecopteris apicalis, diagnosis enmendada, relaciones sistemáticas, Barrueliense, NO España. exploitation in an area close to and previously worked by the now disused mine Pozo Peragido, located between the town of Barruelo de Santullán and the village of Vallejo de Orbó in the province of Palencia (Castilla y León) NW Spain (Fig. 1). The source of the material (UTM coordinates: 396440 E. 4749631 N, European Datum 1950) is dumped overburden derived from working of the seam complex embracing Seams III and IV of the Calero Member of the Barruelo Formation, attributed an early Barruelian age (Wagner \& Winkler Prins, 1985; Wagner, 2009).

This Peragido-Vallejo material has formed the basis for the emended description and diagnosis, drawing also on the holotype specimen from the tip of Pozo Campesinos, also in the vicinity of Vallejo at the eastern end of the Barruelo Coalfield; although from the tip of a mine which worked a number of seams, it may be supposed that this latter specimen derives from working of the Seam V of the Vallejo Block, equivalent to Seam III of the Calero Member (R.H. Wagner, pers. comm.). The holotype, together with collections of material of this species from the Sabero Coalfield as described in Knight (1985), is conserved in the collections of the Centro Paleobotánico, Real Jardín Botánico de Córdoba, Spain. Also contributing to this description is a specimen conserved in the Museo Minero de Barruelo de Santullán, comprising a penultimate pinna with apparent fertile material; this specimen was collected from an opencast working on the Seam VII, at a stratigraphically small interval below the level of the Peragido-Vallejo specimens (see description below of the stratigraphic sequence).

The authors note that in recent decades there has been detailed argument that the classification of Carboniferous fossil foliage should be based on whole-plant systematics, to the extent that it has been proposed that the use of the generic name Pecopteris should be restricted to species with Senftenbergia-like fertile organs (Cleal, 2015). It is accepted that the "whole plant concept" offers a robust and logical basis for the definition of species in the complex group of Pecopteris and its associated organs, where association of sterile and fertile parts can be demonstrated. However, 


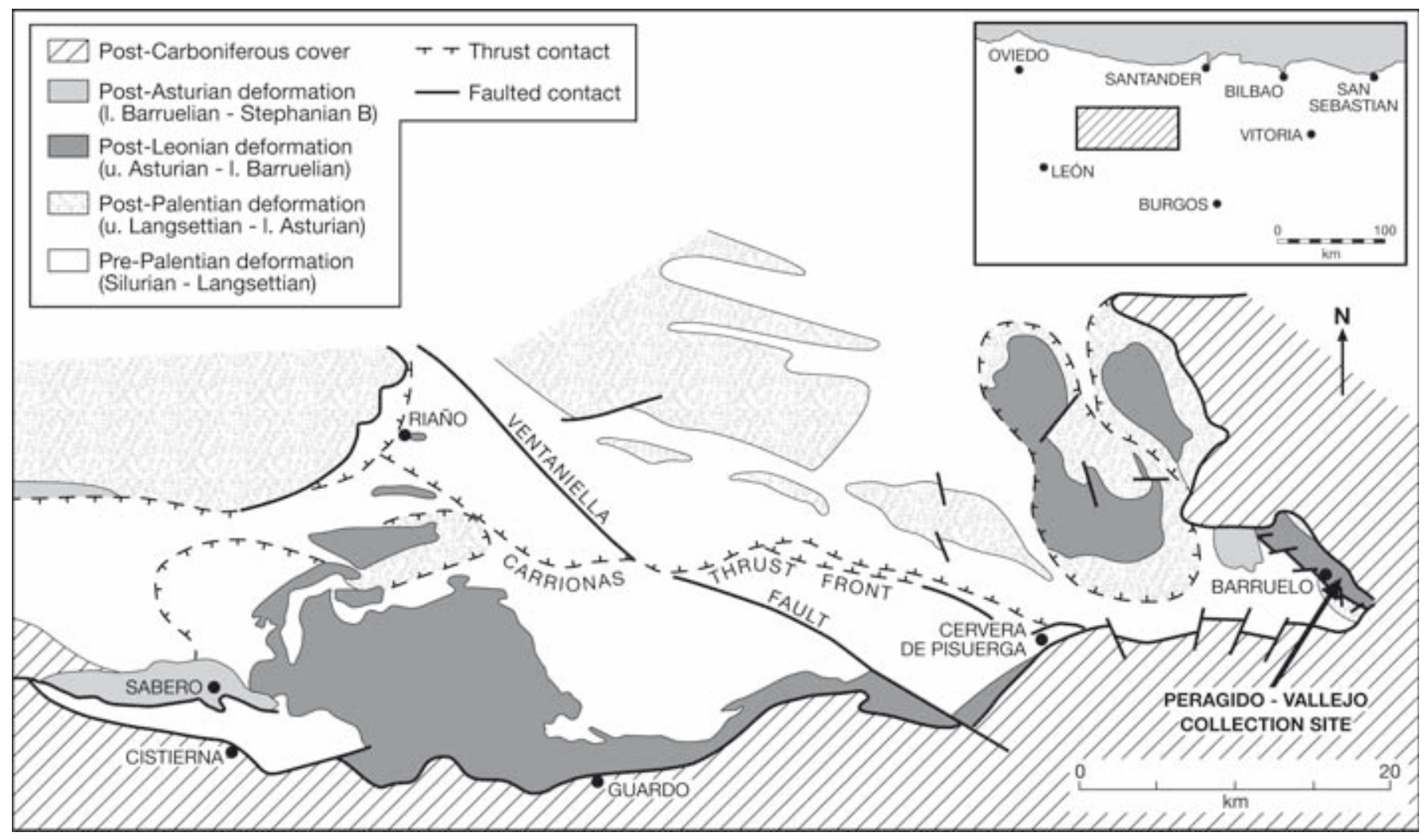

Figure 1. General map of the main tectono-stratigraphic units of the southern flank of the Cantabrian Mountains in NW León and NE Palencia, showing major structural features and the location of the Barruelo and Sabero coalfields and also the collection site of the present material. Map redrawn from Wagner (2009).

this approach offers no satisfactory generic name for vegetative pecopterid material, as described here, without incorporating assumptions as to the fertile organs. For this reason, the fossil generic name Pecopteris is retained for the material here described. The status of the genus Pecopteris and the possible affinities of the presently described species are considered further in discussion below.

\section{MATERIAL}

The large fragments and other material from the PeragidoVallejo site have been only recently collected and are currently stored under the protection of the Museo Minero de Barruelo de Santullán. It is anticipated that some or all of this material may be transferred to the collections of the Centro Paleobotánico, Córdoba, at which time acquisition catalogue numbers will be assigned; a summary listing of type specimens and related material in the latter collections is in preparation for publication. The only fertile material this far recognised for this species is on a slab currently stored by the Museo Minero de Barruelo, collected from an opencast working adjacent to Barruelo Cemetery (UTM
394400 E. 475174 N, European Datum 1950), from Seam VII, a horizon within the Calero Member at a relatively short interval stratigraphically below the seams exploited at the Peragido-Vallejo collection site.

The new and extensive material from the PeragidoVallejo site was collected from a number of large slabs of dark grey silty mudstone, from which over 30 individual specimens show frond organisation as penultimate order pinnae, while additional material comprises over 50 specimens with smaller pinna fragments.

This species was first described in an unpublished thesis (Knight, 1975) and subsequently described formally in Knight (1985), in which the holotype was figured and specified as a specimen collected from the tip of Pozo Campesinos, some $1.7 \mathrm{~km}$ to the east of the PeragidoVallejo collection site. It is here accepted that the holotype should remain as designated. This specimen, together with other material of this species described from the Sabero Coalfield in Knight (1985), is conserved in the collections of the Centro Paleobotánico of the Real Jardín Botánico de Córdoba, Spain. 


\section{SYSTEMATIC DESCRIPTION}

\author{
Genus Pecopteris Brongniart, 1828
}

Pecopteris apicalis Knight, 1985

(Figs 2a-2b, 3a-3b, 4a-4c, 5a-5c, 6, 7a-7c, 8a-8d, 9)

1970 Pecopteris sp. nov. cf. lepidorachis (non Brongniart); Wagner in Wagner \& Winkler Prins, p. 512

1974 Pecopteris lepidorachis (non Brongniart); Knight, p. 289, 292.

* 1985 Pecopteris apicalis Knight; Knight, p. 34-37, pl. 8, figs 1-9; pl. 9, figs 1-3a; text-fig. 5.

. 2005 Pecopteris apicalis Knight; Castro-Martínez, p. $41,44,46,51,55,56,58,59,61,63,67,69,80,87$, lám. 36, figs 1, 2, 4.

2005 Pecopteris cf. apicalis Knight; Castro-Martínez, lám. 36, figs 3,5 .

. 2010 Pecopteris apicalis Knight; Wagner \& ÁlvarezVázquez, p. 276, 282, 283, 309.

Record preceded by $(*)$ provides the definition and illustration of the holotype and diagnosis of the species; records preceded by (.) are accepted by the authors as valid references to material accepted within the diagnosis of the species.

Diagnosis. Large frond, tripinnate, width in excess of $0.80 \mathrm{~m}$. Penultimate rachides robust, width up to $9 \mathrm{~mm}$, with punctate and striate surface. Penultimate pinnae large and parallel-sided, length/breadth ratio between 2.5:1 and $3: 1$; terminal areas most commonly gradually tapering with a transition between a bluntly rounded, fused, triangular terminal, down through a succession of 12-13 pinnules, in which the lower ones are lobing, ultimately pinnatifid, immediately above fully developed ultimate pinnae. Less commonly terminals may show a more gradual transition with the development of a number of long lobed pinnules above the uppermost ultimate pinnae, or in contrast the transition may be rapid giving rise to a bluntly truncated outline of the penultimate pinna. Ultimate pinnae inserted alternately at wide or perpendicular angle, normally touching adjacent pinnae along two-thirds of pinna length; length ranges from $20 \mathrm{~mm}$ in near terminal areas to 100 $\mathrm{m}$, with $1 / \mathrm{b}$ ratio most commonly $6: 1$ to $7.5: 1$. Terminal area of ultimate pinnae with a gently convergent margin over the distal third of the total pinna length, with an acuminate bluntly rounded fused terminal. Longest pinnae (over $80 \mathrm{~mm}$ ) show up to 45 successive pinnule insertions before the terminal area; rachides robust, widths 0.5-1.0 $\mathrm{mm}$ and roughly striate, often rugose, suggestive of short hairs. Pinnules parallel-sided with a broadly rounded or acuminate top, closely arranged with pinnule margins normally touching over lower half and sometimes overlapping. Most common pinnule dimensions 3.0-5.5 mm with $1 / \mathrm{b}$ ratio $2.0: 1$ to $3.0: 1$. Longer pinnules may attain $8 \mathrm{~mm}$ length with maximum $1 / \mathrm{b}$ ratio $4: 1$. Insertion of pinnules consistently perpendicular to ultimate rachis. Midvein straight extending to close to the summit of pinnule; lateral veins consistently once-bifurcate, forking immediately on or adjacent to the mid-vein. Density of venation along the pinnule margin consistent in the range 22-30 vein endings/cm. Fertile material represented only as indistinct circular sori or synangia, diameter approximately $0.7 \mathrm{~mm}$, arranged in series of up to 5 spaced on either side of the mid-vein, reminiscent of but incompletely defined for attribution to Asterotheca Presl.

Organisation of the frond. Within the wide range of material available for description, no fragment has been identified which shows organisation above the level of penultimate order pinna. One specimen only shows the apparent, but poorly defined, insertion of the penultimate order rachis on to an antepenultimate rachis (or petiole in the usage of Zodrow, 1990); this specimen is figured as Figure $2 \mathrm{a}$ with the corresponding schematic frond model as Figure $2 \mathrm{~b}$. This indicates that the large penultimate pinnae were borne on a frond (of antepenultimate pinnate order) which will have had an overall width of at least $0.80 \mathrm{~m}$ and potentially a length in excess of $2.0 \mathrm{~m}$. The antepenultimate rachis, or petiole, on which direct connection to the pinnae cannot yet be confirmed, has a compressed width of $8 \mathrm{~mm}$, with a fibrous, longitudinally striate surface.

The large, well preserved penultimate pinnae, which frequently overlie each other with separating layers of sediment of 4-10 mm, suggest minimal transport from their growth location. No fragments indicative of potential stem compressions associated with an arborescent habit have been found in the associated sediments. There is a wide range of pinnule and pinna size in the available vegetative material, indicative of different positions in a large and relatively varied frond structure. It may be envisaged that this reflects a succession of fronds arising from a dense crown which may have been borne on a stem structure of greater or lesser stature.

Pinnae of penultimate order. Some six of the largest examples of penultimate order pinnae demonstrate a length in excess of $300 \mathrm{~mm}$ (Figs 2a, 3b, 4a). The longest continuous penultimate pinna fragment attains $360 \mathrm{~mm}$ without definition of the basal insertion. Penultimate pinnae appear most commonly to be parallel-sided over the greater part of their length, with the longest specimens showing widths of $120-140 \mathrm{~mm}$, although individual last order pinnae suggest the width of the penultimate pinna may have attained $200 \mathrm{~mm}$. Over 36 successive last order pinnae may be borne on a penultimate order pinna.

The present material shows considerable variation in the characteristics of the terminal area of penultimate pinnae. The shape of the terminal area is governed by a 

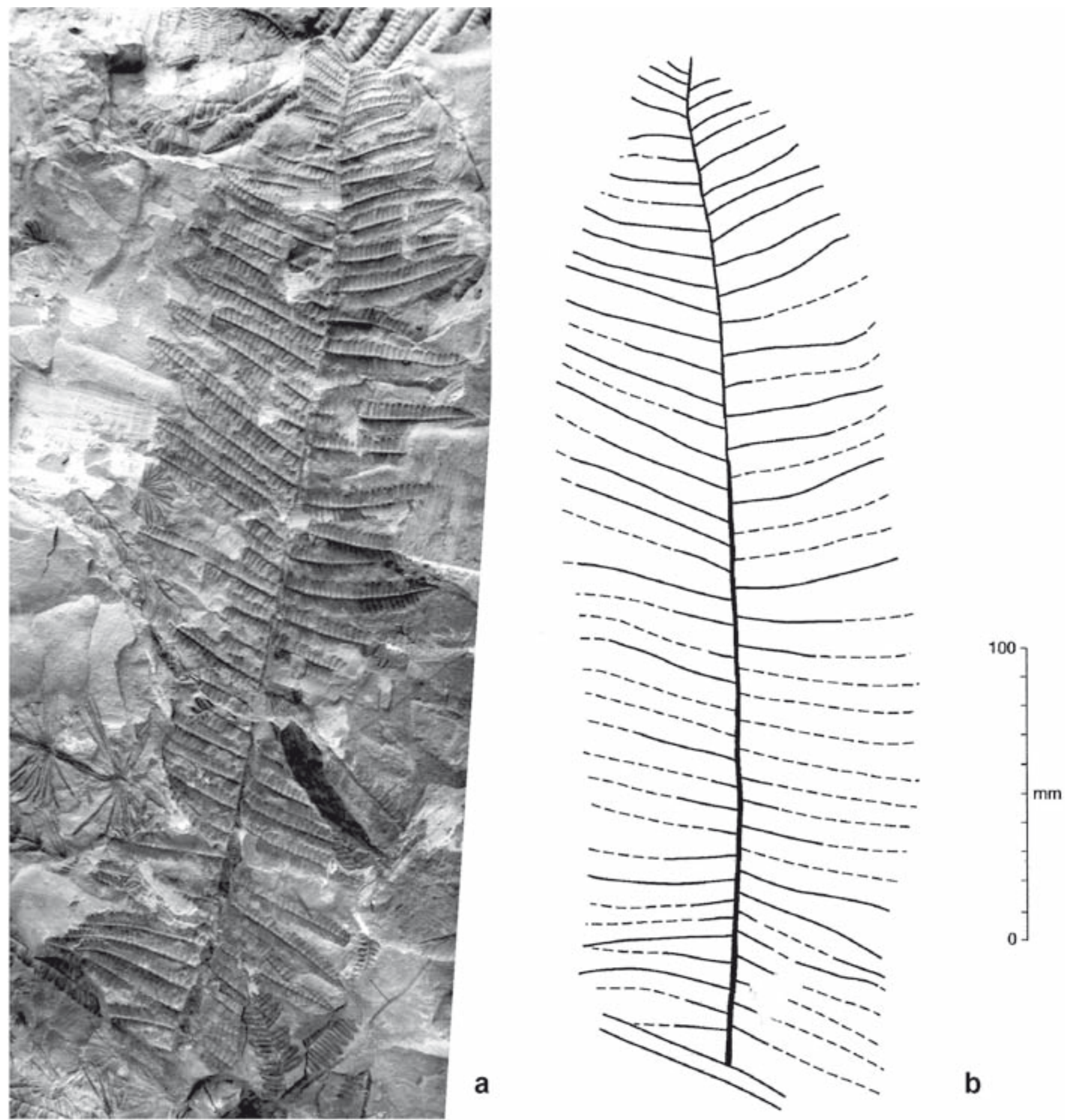

Figure 2. Pecopteris apicalis Knight. a) Penultimate order pinna (x 0.5). Note apparent but inconclusive connection to rachis of tripinnate order. Specimen from Peragido-Vallejo collection site. b) Schematic frond diagram of specimen in Fig. 2a (x 0.5).

constant feature which is that the penultimate pinna shape always remains only very gradually tapering or even parallel-sided up to the terminal area (see schematic frond models on Figs 2b, 3a), always where pinnae are fully developed, but thereafter displays a marked tapering of the pinna margins from the point where there is transition towards the apex from fully developed pinnae to long lobing pinnatifid pinnules. This transition may be more or less rapid in terms of the number of pinnules between the terminal and the most distal ultimate pinna and this governs the acuteness of the tapering of the penultimate pinna terminal area. Considerable variation is displayed in terms of the acuteness of tapering and the rapidity of transition through pinnatifid and lobing pinnules to simple pinnules adjacent to the terminal pinnule. 
The most distal terminal area of penultimate pinnae is rarely preserved. The specimen in Figure $5 \mathrm{~b}$ shows the terminal to be bluntly rounded and weakly fused into a small, broad triangular terminal pinnule. This terminal demonstrates a transition through a succession of 12-13 pinnules, in which the lower ones are lobing, ultimately pinnatifid and finally become fully developed last order pinnae; in this case the gradually tapering terminal area has an internal angle between the convergent margins of around $35^{\circ}$. Similar development is indicated in the specimen on Figures $4 \mathrm{a}-4 \mathrm{~b}$, also illustrated graphically as Figure 6. In contrast, some of the larger penultimate order pinnae (Figs 2a-2b, 3a-3b) suggest a more rapid transition of some 7-8 pinnules between the terminal and the most distal of the last order pinnae, associated with a more rapidly tapering terminal area with an internal angle of approximately $75^{\circ}$, giving a very blunt pinna outline. Of apparently less common occurrence are smaller penultimate order pinnae in which the transition from lobing through pinnatifid pinnules to fully developed last order pinnae is very gradual, within a long tapering terminal area; this is illustrated in Figure 5a, in which the succession of long lobed pinnules may exceed 7 or 8 in number before the fully pinnate stage is achieved and longest lobed pinnules are up to $27 \mathrm{~mm}(1 / \mathrm{b}$ in excess of 5.5:1). An apparently exceptional specimen is figured
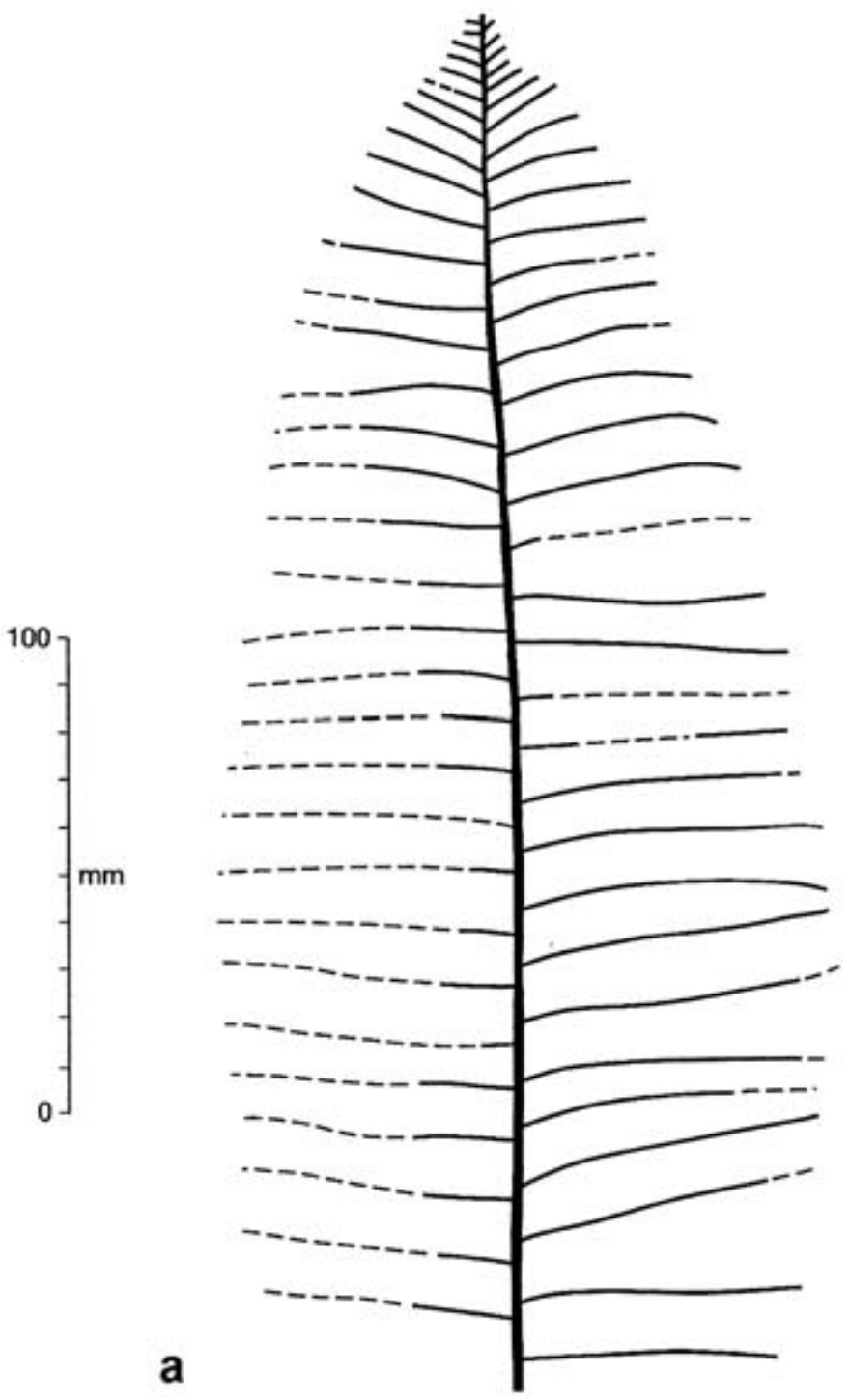

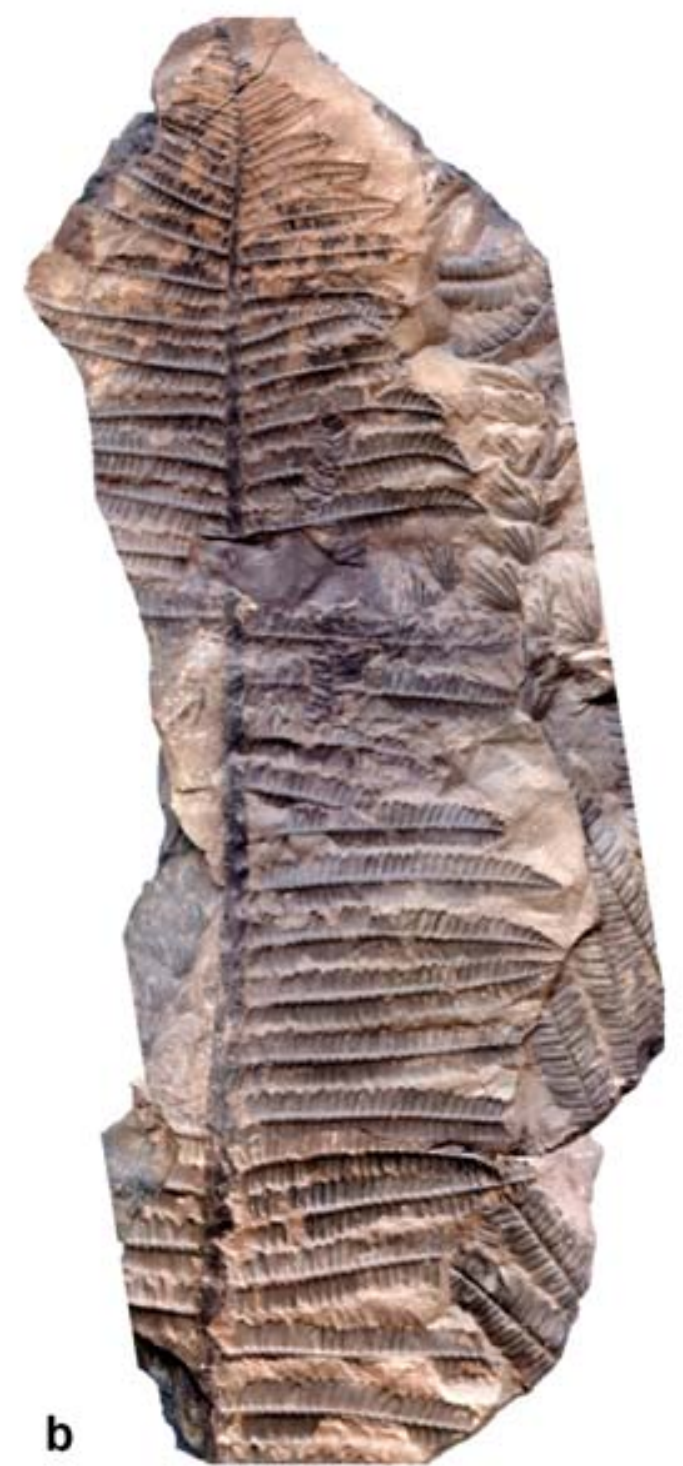

Figure 3. Pecopteris apicalis Knight. a) Schematic frond diagram of specimen in Fig. 3b (x 0.5). b) Penultimate order pinna (x 0.5). Specimen from Peragido-Vallejo collection site. Note material of Polymorphopteris polymorpha (Brongniart) Wagner in the underlying lamina. 

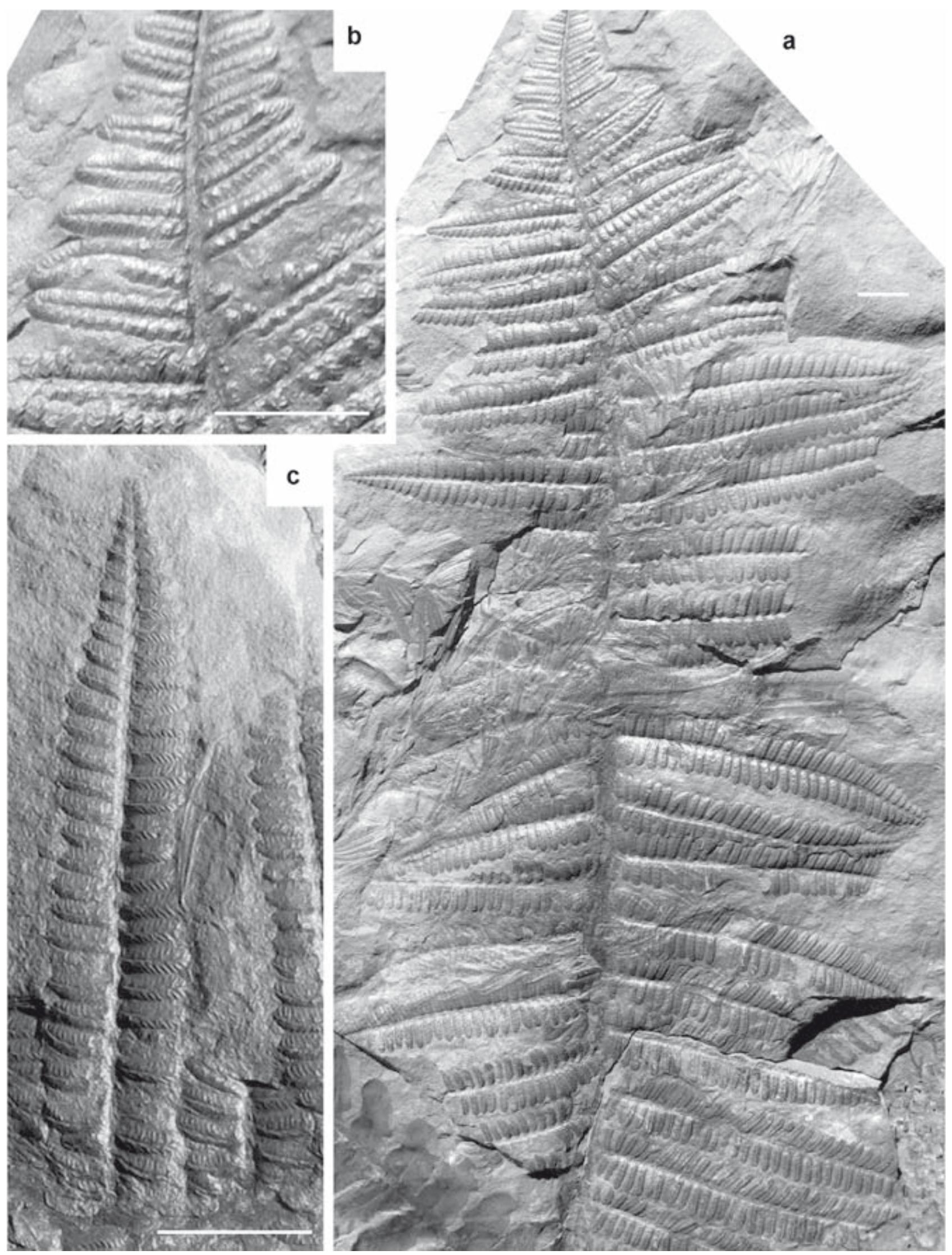

Figure 4. Pecopteris apicalis Knight. a) Penultimate order pinna (x 1). Specimen from Peragido-Vallejo collection site. Note material of Neuropteris ovata Hoffmann in the underlying lamina. b) Terminal area of penultimate order enlarged from specimen in Fig. 4a (x 3). c) Last order pinna enlarged, from the upper right-hand sector of the specimen in Fig. 4b (x 3). Scale bar $1 \mathrm{~cm}$ for all figures. 
as Figure 7a, in which the transition is extremely rapid through some six or seven pinnules and the length of the more distal last order pinnae is greatly in excess of the transition pinnules and these define the most distal margin of the pinna outline, so that the overall pinna shape is very blunt and even rectangular. In summary the shape of the terminal area of penultimate pinnae varies from gently and acutely tapering to blunt and truncated.

A characteristic feature of penultimate pinnae is that the most basal (proximal) ultimate pinnae are relatively shorter than successive pinnae and are strongly deflected downwards towards the antepenultimate rachis which they appear to cover (Figs 2a, 5a).

Rachides of penultimate pinnae. Rachides are very robust and in a number of specimens show a maximum width of $9 \mathrm{~mm}$ (Figs 7c, 8a). The surface of the rachis is weakly striate and consistently punctate, indicating the presence of hairs or fine spines. The rachis appears to have been most prominent on the underside of the frond; insertion of last order pinnae on the circumference of the rachis appears to have been relatively higher to coincide with the plane of the top surface of the frond, with a tendency for the insertion of last order pinnae to fold towards the centre of the top surface of the rachis so that in preservation the full width of the rachis may be obscured.

Ultimate pinnae. The last order pinnae are inserted alternately along the rachis at a very wide angle ranging from near perpendicular to widely inclined $\left(75^{\circ}-85^{\circ}\right)$. Only in near terminal areas of penultimate pinnae do the ultimate pinnae become more inclined at angles approaching $60^{\circ}$. Adjacent pinnae are normally touching along more than two-thirds of the pinna length and frequently overlap.

Dimensions of ultimate pinnae range from a maximum length of $100 \mathrm{~mm}$ (width $15 \mathrm{~mm}$ ) to a minimum in near terminal areas of length $20 \mathrm{~mm}$ (width $4 \mathrm{~mm}$ ); by far the most common dimensions are for pinnae of length 60-70 $\mathrm{mm}$ with width $9-10 \mathrm{~mm}$. Pinnae are generally parallelsided (Fig. 5c); the length/breadth ratio is most commonly in the range $6: 1$ to $7.5: 1$. Exceptionally longer pinnae show a length/breadth ratio of up to 8.5. Pinnae in near-terminal areas (length approximately $20 \mathrm{~mm}$ ) commonly show a more tapering shape and show the lowest length/breadth ratio of around 4:1.

The number of pinnules on a pinna is very variable in proportion to the length. Longest pinnae (over $80 \mathrm{~mm}$ ) show up to 45 successive pinnule insertions before the terminal area (Fig. 7a). The more common pinnae of length 60-70 mm generally show 26-35 successive pinnules, while shorter near-terminal pinnae of length $20-40 \mathrm{~mm}$ show from 14-20 successive pinnules.

Pinnules are generally inserted alternately along the length of the pinna and are closely spaced along the pinna, giving an aspect of rigidity.
Terminals of ultimate pinnae. Most commonly the terminal area of ultimate pinnae is characterised by a gently convergent margin over the most distal third of the total pinna length. This culminates in an acuminate bluntly rounded fused terminal comprised by a small rounded triangular apex lobe fused with the successive two immediately adjacent distal lobes of the pinna, which are at this point insufficiently developed into pinnules (Figs $4 \mathrm{c}, 7 \mathrm{~b}, 8 \mathrm{~d}$ ). Some variation is apparent where some terminal areas appear more slender and the fused area of the terminal is more narrowly acute and may comprise up to five fused lobes (e.g., on specimen illustrated as Fig. 5a). In pinnae with relatively longer pinnules the convergent area at the summit of the pinna appears more abrupt (tapering occurs only in the most distal one-sixth of the pinna length) in which cases the fused terminal gives a bluntly rounded triangular element (Fig. 5c). Near the terminal of penultimate pinnae, the smallest ultimate pinnae generally have more fused and broadly rounded terminal areas (see Fig. 6).

Rachides of ultimate pinnae. Rachides of ultimate pinnae are robust; they appear more strongly marked and prominent on the underside of the ultimate pinnae, with apparent widths of from $0.5 \mathrm{~mm}$ up to $1.0 \mathrm{~mm}$. The insertion of pinnules appears to be on the upper sector of the circumference of the rachis, so that the upper surface of the last order pinna shows a somewhat more narrow rachis, commonly of around $0.6 \mathrm{~mm}$, depressed below the plane of the surface of the pinna; on compression the base of pinnules may appear to converge over the rachis. On the upper surface of the pinna the rachis appears roughly striate, while on the lower surface of the pinna the rachis is more roughly striate, of more rugose appearance offering the suggestion that the this side of the rachis was covered with short hairs.

Pinnules. The range of material demonstrates considerable variation in pinnule size. The most characteristic material, of common occurrence on ultimate pinnae, demonstrates pinnule lengths ranging $3.0-5.5 \mathrm{~mm}$ with corresponding widths of $1.5-2.0 \mathrm{~mm}$, with a length/ breadth ratio in the range 2:1 to $3: 1$. Large fragments of penultimate order pinnae show that longest pinnules on ultimate pinnae may attain $8 \mathrm{~mm}$ with a width of $2 \mathrm{~mm}$ (Figs $7 \mathrm{a}, 7 \mathrm{c}$ ). In contrast, in particular near the terminal areas of penultimate pinnae, and specifically those with acutely tapering terminals (Figs 5a, 6), there is a gradual progression through very long lobing pinnules to the uppermost ultimate pinnae; the succession of long lobed pinnules may exceed 7 or 8 in number before the fully pinnate stage is achieved. Longest lobed pinnules are up to $27 \mathrm{~mm}(1 / \mathrm{b}$ in excess of 5.5:1) immediately above the highest ultimate pinnae, which are characterised by very small pinnules of which the smallest clearly defined 

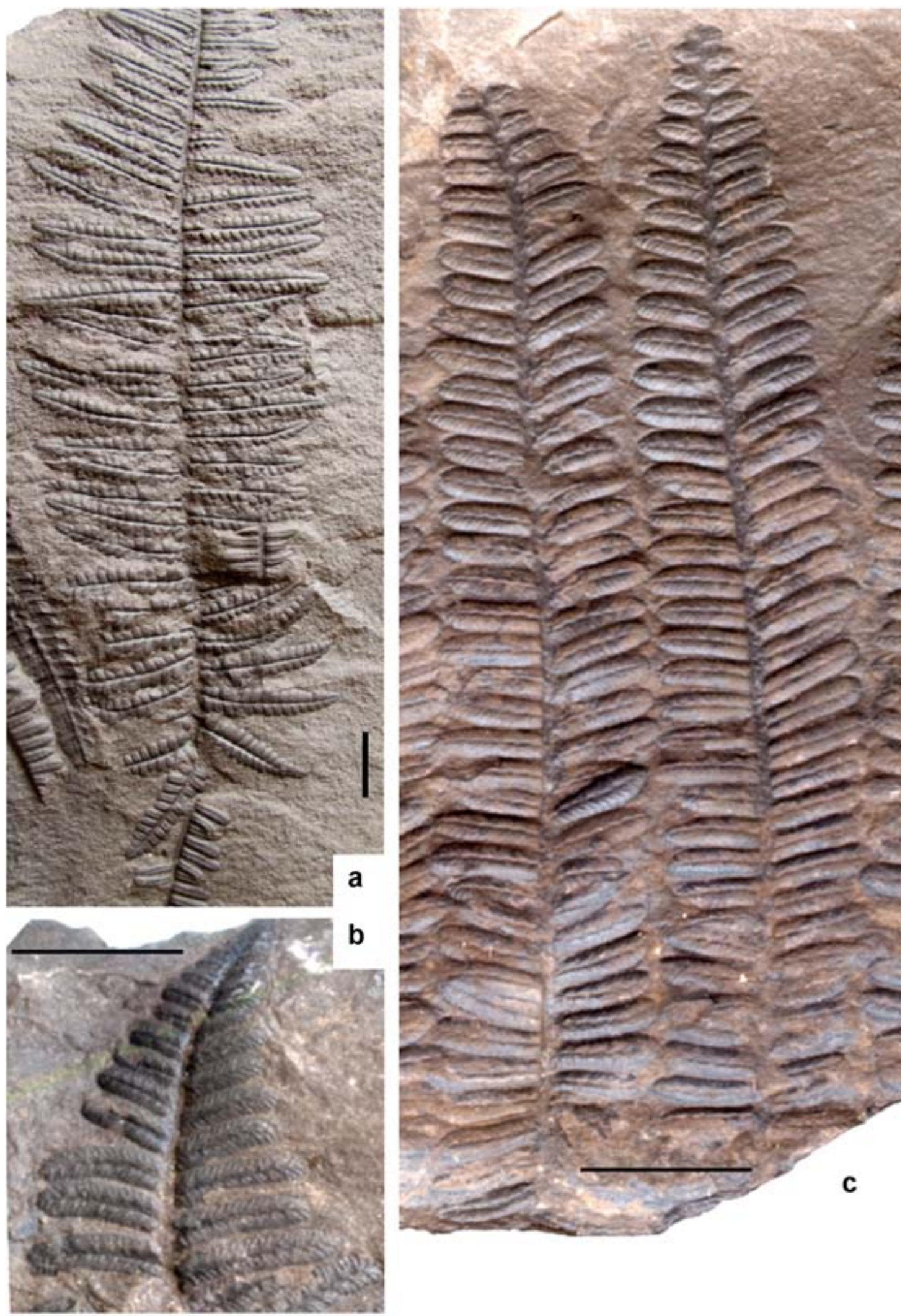

Figure 5. Pecopteris apicalis Knight. a) Penultimate order pinna showing the relatively less common, very gradual transition in the terminal area, from long lobing pinnules, through pinnatifid pinnules to slender last order pinnae with small, squat pinnules (x 1). b) Terminal area of penultimate order showing characteristic tapered profile and transition between elongate nearterminal pinnules and last order pinnae (x 3). c) Last order pinnae showing characteristic more elongate pinnules with acuminate top and apparently more individualised terminal element (x 3). All material on this figure from the PeragidoVallejo collection site. Scale bar $1 \mathrm{~cm}$ for all figures. 


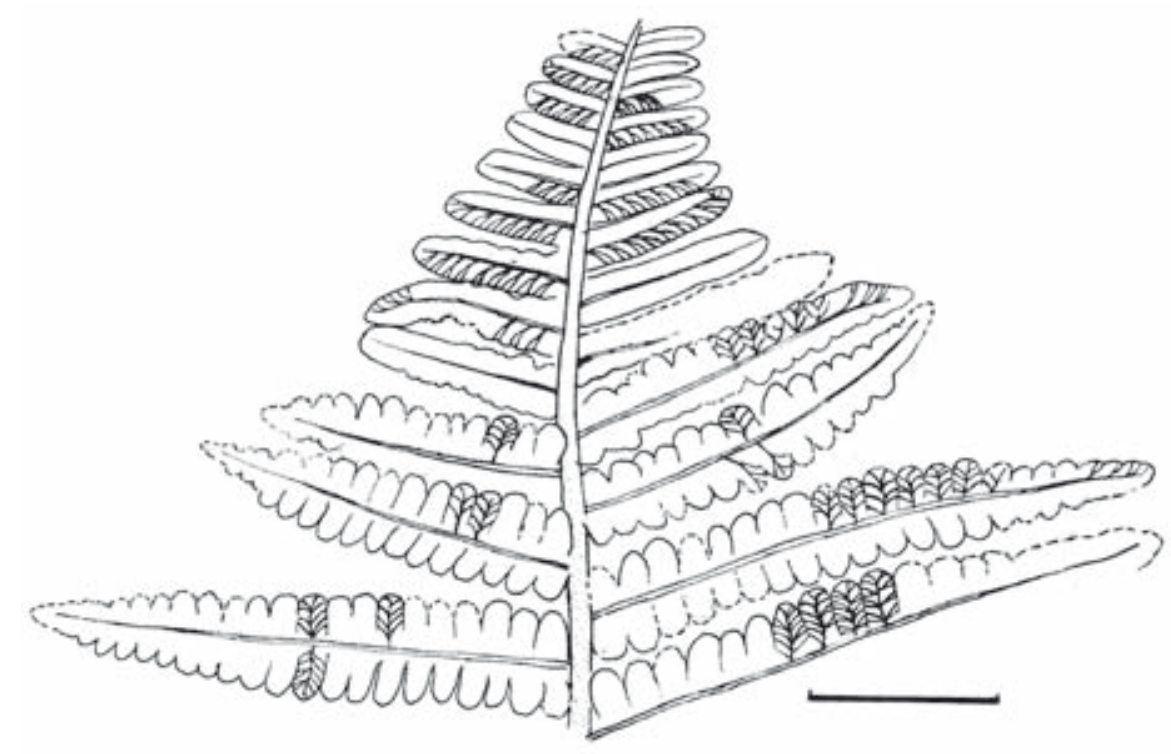

Figure 6. Tracing of pinnule shape and venation in the terminal area of a large penultimate order pinna; tracing of the specimen illustrated on Figs 3a, 3b. Scale bar $=1 \mathrm{~cm}$. pinnules are of $1 \mathrm{~mm}$ length and width $0.8 \mathrm{~mm}$ (length/ breadth ratio of approximately $1.3: 1$ ).

All pinnules are parallel-sided with a broadly rounded or acuminate top. Pinnules are characteristically closely arranged with pinnule margins touching and sometimes overlapping, but longer pinnules have a more acuminate top, although where vaulted and margins appear inrolled, the insertion may appear more spaced (lower pinnae of specimen in Fig. 7a). Insertion on the last order rachis of longer pinnules is consistently perpendicular to the rachis; the more commonly occurring range of pinnules are inserted at a broadly inclined angle ranging $70^{\circ}-85^{\circ}$ on the last order rachis. Pinnules at the base of ultimate pinnules commonly show a more open insertion so that they are flexured back to cover part of the rachis.

The pinnule limb appears to have been relatively delicate but rather vaulted; the vaulted surface contributes to the appearance of slight constriction of the pinnule base in some areas of the pinna. The venation appears to be well-marked and apparently raised on the upper surface of the pinnule.

Venation. Pinnules show a well-defined, straight midvein which extends to close to the summit of the pinnule. The mid-vein appears to arise directly straight from the rachis and only rarely a deflexed base can be observed arising from the rachis. Lateral veins are consistently once bifurcate; they arise at a wide angle from the midvein and fork immediately on or adjacent to it. The lateral veins are consistently curved in a wide arc, and in particular on the acroscopic side attain the pinnule margin at a near-perpendicular angle, which may be more oblique on the basiscopic side. In elongate pinnules the lateral veins may be less strongly curved and may attain the margin of the pinnule at a more oblique angle. Figure 9 illustrates the venation pattern from a range of foliage in the Sabero Coalfield, as illustrated in Knight (1985); this corresponds wholly with the venation observed in the pinnules on common ultimate pinnae from the PeragidoVallejo material.

The wide range of material now available illustrates the transition in near-terminal areas from a succession of elongate lobed pinnules to ultimate pinnae with very small pinnules (Fig. 6). Lobed pinnules show a very rapid transition within a single pinnule from the bifurcate vein pattern to a multipronged cluster of single veins within a lobe. Near the point of transition to fully defined pinnules, the smallest pinnules show single veins arising from a midvein which may show a perpendicular or weakly decurrent insertion to the rachis. The transition to more characteristic pinnules with bifurcate venation is generally relatively rapid over two successive pinnules.

The density of venation measured along the pinnule margin is relatively open and consistent in the range 2230 vein endings $/ \mathrm{cm}$. In shorter pinnules, less than $4 \mathrm{~mm}$ long, venation is at its most dense, showing wider values in longer pinnules.

Fertile material. Amongst the Peragido-Vallejo specimens only one small terminal fragment shows any indication of a fertile state (Fig. 8c). Very indistinct rounded impressions with undulating margins, of maximum diameter $0.7 \mathrm{~mm}$ occur in rows of up to 5 along one or other side of the position of the mid-vein. However, the specimen collected from Seam VII near Barruelo Cemetery (Figs 8a-8b) displays more clear evidence of the fertile condition. The character of individual sori or synangia is indistinct but the material shows the regular occurrence 

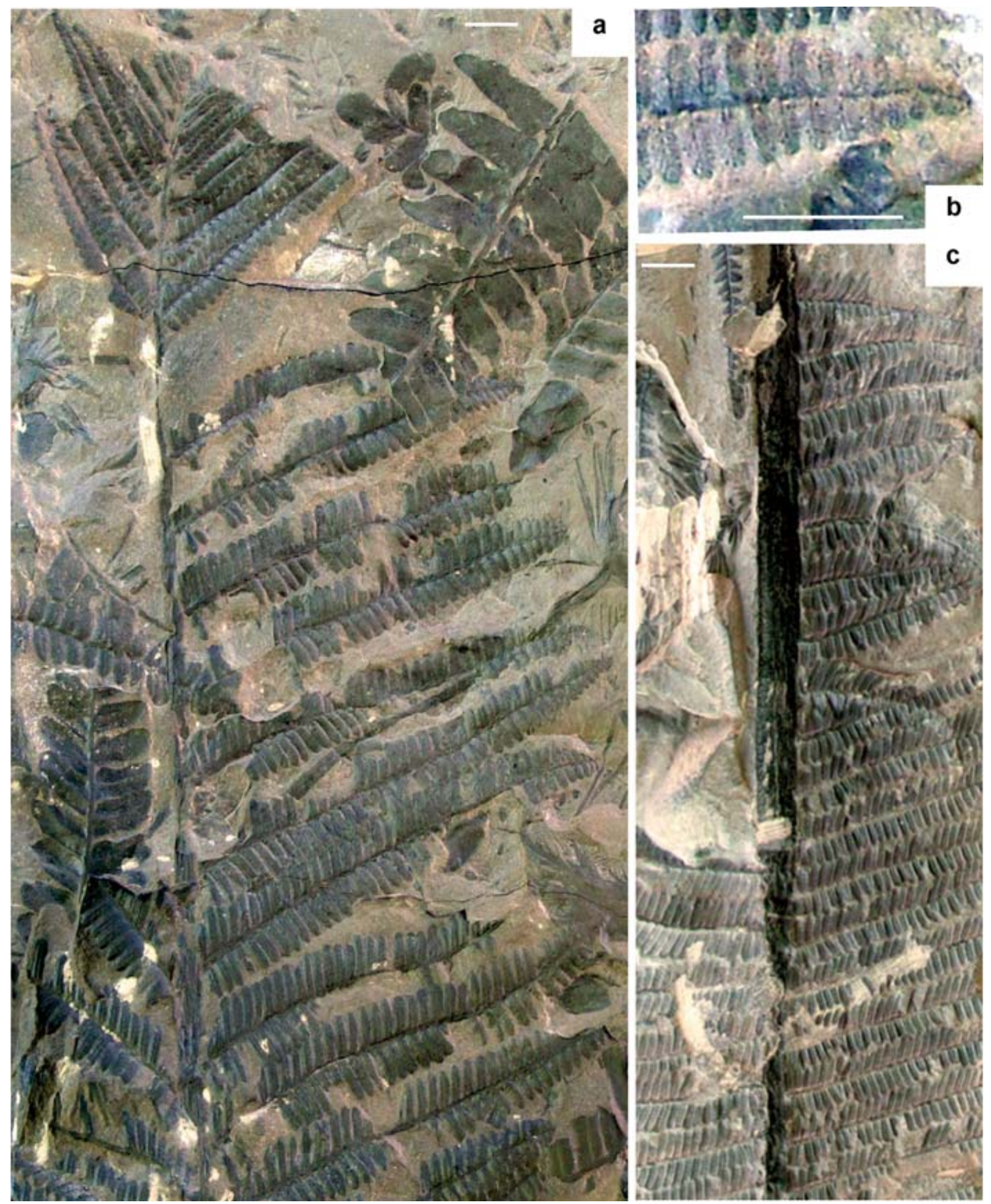

Figure 7. Pecopteris apicalis Knight. a) Penultimate order pinna; terminal area shows an exceptional blunt profile with very rapid transition between elongate pinnules and very long uppermost last order pinnae. Note pinnae of Neuropteris ovata Hoffmann on the same preservation plane (x 1). b) Terminal of last order pinna (x 3). c) Penultimate order pinna showing very thick, punctate rachis of penultimate order (x 1). All material on this figure is from the same slab and preservation surface, Peragido-Vallejo collection site. Scale bar $1 \mathrm{~cm}$ for all figures. 

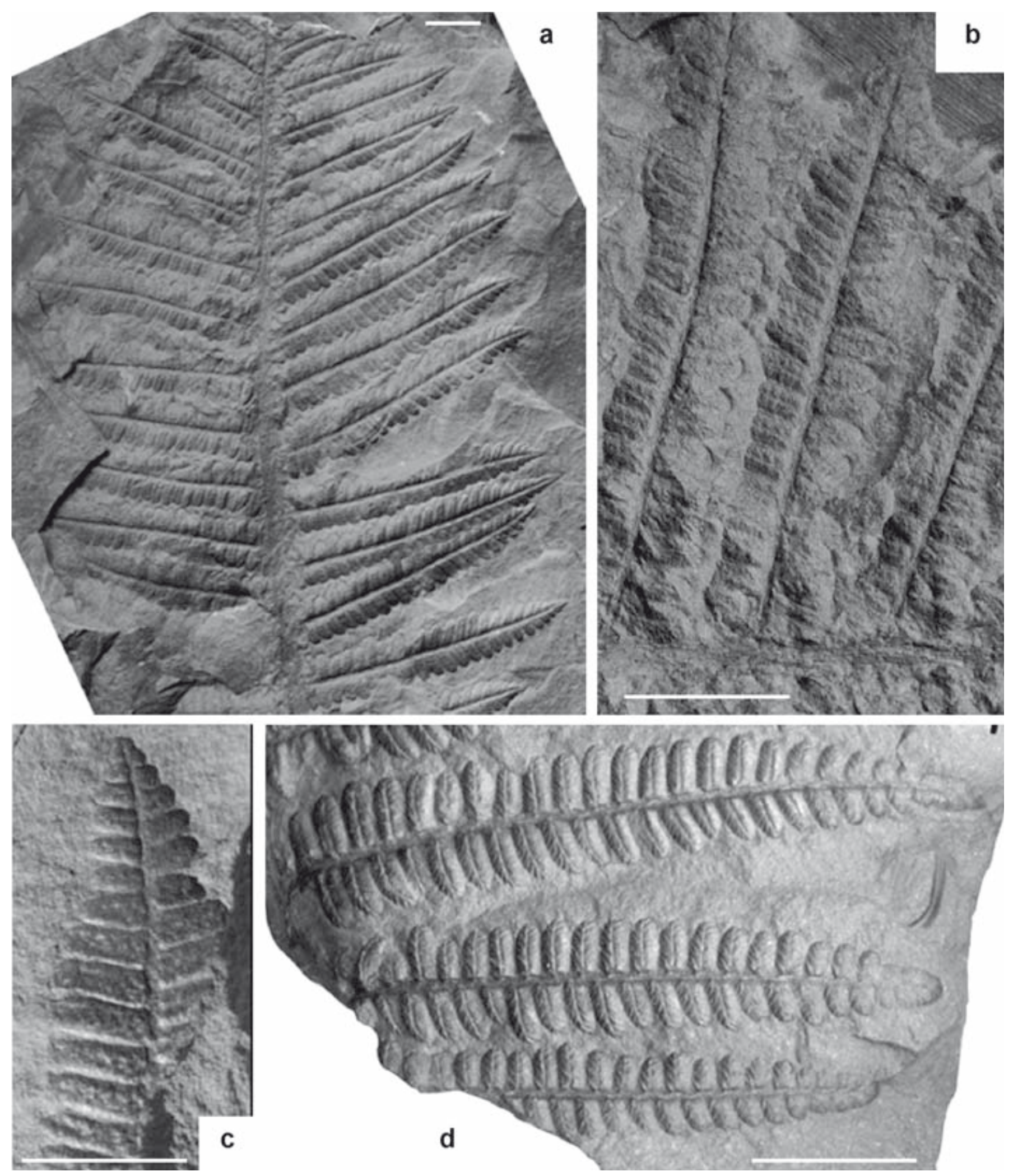

Figure 8. Pecopteris apicalis Knight. a) Penultimate order pinna (x 1); on last order pinnae the pinnules show small sori or synangia arranged in a row along either side of the mid-vein. Specimen collected from opencast working on Seam VII near Barruelo Cemetery. b) Enlargement of last order pinnae from the top left-hand area of the specimen on Fig. 8a, illustrating size and location of sori (x 3). c) Terminal of last order pinna (x 3) from the Peragido-Vallejo collection site; the only specimen from this location with indication of possible fertile organs. d) Last order pinnae (x 3) from the Peragido-Vallejo collection site. Scale bar $1 \mathrm{~cm}$ for all figures. 


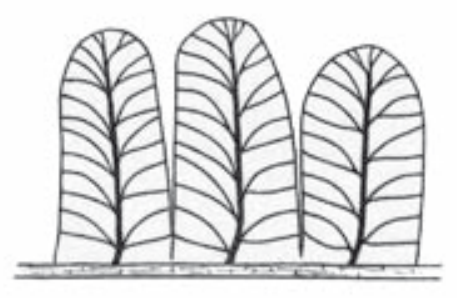

a

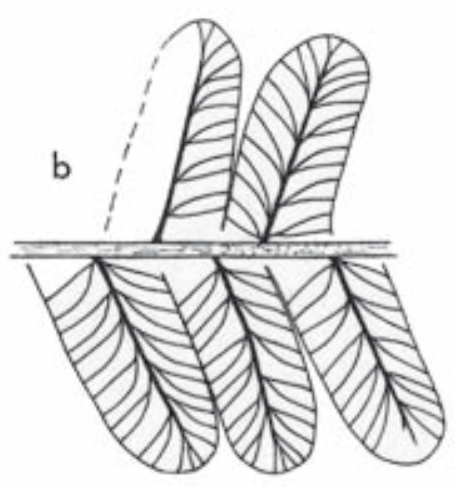

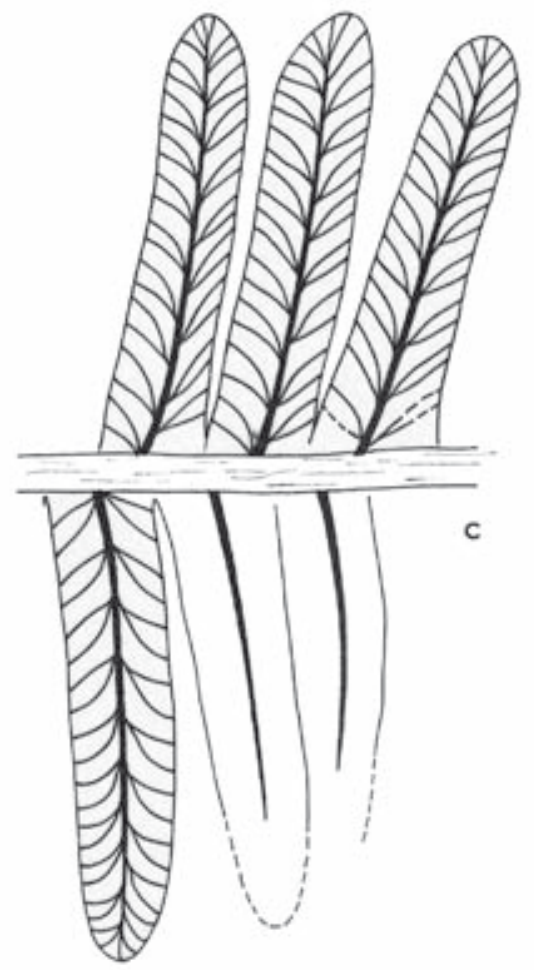

Figure 9. Venation diagrams (x 6) of pinnules of Pecopteris apicalis, from specimens from the Sabero Coalfield (from Knight, 1985).

$\mathrm{Icm}$

of rounded organs with undulating margins, diameter up to $0.7 \mathrm{~mm}$, arranged in two rows each of up to six, on either side of the pinnule mid-vein. Up to 12 successive ultimate pinnae in the near terminal area show the presence of fertile organs. Unfortunately the state of preservation is insufficient to allow further identification of the nature of these sori or synangia, although this type of fertile material in compression is strongly suggestive of an attribution to the genus Asterotheca Presl.

\section{COMPARISONS}

The comparisons made in the original description of this species (Knight, 1975, 1985) focussed on pecopterid compression material with venation characterised by consistently bifurcate veins. This remains the primary criterion which limits comparison to a relatively small group of species with which Pecopteris apicalis may be confused. However, the existence of numerous species of superficially similar pecopterid foliage erected on limited type material, and the sometimes erroneous identifications attached to such material in the literature, gives scope for some confusion for the identification of this species.
With respect to comparable species in the coalbearing sequences of Stephanian age in Western Europe, primary comparisons are in those assemblages in the macrofloral biozones, as designated by Wagner (1984), corresponding to the range here recognised for $P$. apicalis. These comparisons assist characterisation of the present species in the context of the floras designated as the Odontopteris cantabrica (Cantabrian), Lobatopteris lamuriana (Barruelian) and Alethopteris zeilleri (Saberian) megafloral zones (Wagner, 1984; Wagner \& ÁlvarezVázquez, 2010). Comprehensive lists and documentation of species recognised in these zones in the Iberian Peninsula have been provided in Wagner \& Álvarez-Vázquez (2010).

This type of material has commonly been identified with the species Pecopteris densifolia (Goeppert) Weiss and/or P. lepidorachis Brongniart. Both species present difficulties for identification, and both species appear in the revised lists of Wagner \& Álvarez-Vázquez (2010) for the Iberian Peninsula with qualification (respectively Pecopteris cf. lepidorachis in Cantabrian records and $P$. cf. densifolia in Barruelian and Saberian records).

This type of material has frequently been assigned to Pecopteris lepidorachis, as discussed in Knight (1985). Considerable confusion surrounds $P$. lepidorachis, but inspection of Brongniart's type specimen (in the Muséum 
d'Histoire Naturelle, Paris) clarified its distinction from $P$. apicalis. In the holotype of $P$. lepidorachis pinnules are over $10 \mathrm{~mm}$ long and very elongate with an $1 / \mathrm{b}$ ratio of $5: 1$, and are thus more elongate and longer than pinnules of $P$. apicalis. More importantly for identification, the venation in P. lepidorachis consists predominantly of three-pronged veins and the density of venation is over 35 vein endings/ $\mathrm{cm}$. In contrast, no three-pronged veins occur even in the longest pinnules of $P$. apicalis, in which venation density in correspondingly long pinnules is markedly wider. In $P$. lepidorachis any once-forked veins have a tendency to fork well away from the mid-vein, in contrast to the tendency in $P$. apicalis for the bifurcation to occur close to the mid-vein.

It is normally the much larger size of material generally assigned to Pecopteris densifolia which offers the clear distinction from $P$. apicalis. The longest pinnules of $P$. apicalis may approach the normal length illustrated for $P$. densifolia but are more elongate in shape (1/b 4:1) with more acuminate tops in contrast to the more rounded pinnules of $P$. densifolia which appear consistently to show broader dimensions (1/b 3:1). The smallest pinnules of $P$. densifolia are most liable to confusion with this species but they occur only near pinna terminals and rapidly grade to normal, larger pinnules. Pinnules of $P$. apicalis which have the same proportions as those of $P$. densifolia are considerably smaller (6 $\mathrm{mm}$ long) and have a denser venation; this latter feature varies with pinnule length in $P$. apicalis whereas it remains constant in $P$. densifolia. In the latter, veins are less strongly arched, more oblique to the margin and they are frequently twice forked, whereas this is never seen in P. apicalis.

Some closely set elongate pinnules are very closely comparable in shape and size with pinnules of Pecopteris cyathea (von Schlotheim) Brongniart, a species also identified in the Saberian succession of the Iberian Peninsula (Wagner \& Álvarez-Vázquez, 2010). However, they are readily distinguished by the type of venation, which in $P$. cyathea consists of denser (over 32 vein endings $/ \mathrm{cm}$ ), straight, oblique thin veins, in which there is a random admixture of single and once-forked veins, which fork at variable distances from the mid-vein but not on it. Terminals of last order pinnae are also more squat and broadly rounded in P. cyathea.

Close comparison is also possible with Pecopteris hispanica Wagner, a species described from the Saberian succession of the Ciñera-Matallana Coalfield, laterally equivalent to horizons in the Sabero Coalfield from which P. apicalis has been described (Knight,1985). P. hispanica was originally described and figured as Pecopteris permica Němejc (Wagner \& Artieda, 1970) but was later erected as a new species (Wagner, 1985), in the discussion of which, the close similarity with other members of the Pecopteris arborescens-cyathea group was commented in detail, including comparison with P. apicalis. P. hispanica certainly presents close superficial similarity to $P$. apicalis in general frond organisation, pinna and pinnule shape and size. However, the pinnules of $P$. hispanica display rather broader proportions $(1 / \mathrm{b}$ ratio in figured material not exceeding 2.5:1) than in $P$. apicalis, reflected in a more consistently rounded pinnule shape in conjunction with a more robust appearance. The most striking difference lies in the venation; $P$. hispanica shows a more strongly marked mid-vein and displays a mixture of single and once bifurcate veins. Veins are more or less straight, of rigid appearance and bifurcations occur at or beyond the mid-point between the mid-vein and pinnule margin, in contrast to the consistently once-bifurcate veins in $P$. apicalis, which fork only at or very close to the mid-vein and display a curved, strongly arched style.

The only record of Pecopteris treviranii (Goeppert) Presl from equivalent successions in the Iberian Peninsula is that from the Sabero Coalfield (Knight, 1985; Wagner \& Álvarez-Vázquez, 2010). The close similarity with $P$. apicalis of the material assigned to $P$. treviranii was noted by Knight (1985). Nevertheless, it remains clear that the material assigned to $P$. treviranii from the Sabero Coalfield is a different form-species, taking into account the wide range of material now available for characterization of $P$. apicalis. $P$. treviranii has not been widely recognised, perhaps reflecting that the original description was based on a single specimen comprising two ultimate pinna fragments (Goeppert, 1836); Goeppert describes the pinnule bases as confluent and specifies that lateral veins are three-pronged and the fertile organs are a double row of elongated sori along the length of lateral veins. The species was recognised and illustrated by Corsin (1951) from the upper part of the Assise de la Houve in the Sarre-Lorraine Coalfield, from a horizon attributable to the Asturian (= Westphalian D) substage of the West European chronostratigraphic framework. Corsin's relatively extensive illustration provided the basis for the comparisons summarised in Knight (1985). Ultimate pinnae have a long slender appearance, tapering only in the upper third to a small rather fused terminal, rather similar to that seen in $P$. apicalis, and venation style and density also appears similar, but is less distinct reflecting an apparently thicker pinnule limb and thinner, less prominent veins. Pinnules have a range of proportions similar to those of $P$. apicalis, but in the relatively limited range of material attributed to $P$. treviranii pinnules appear larger and characteristically more slender. However, pinnule bases in $P$. treviranii appear consistently confluent and Corsin stresses the "alethopteroid" nature of the pinnules, with a decurrent mid-vein, on the basiscopic side of which the most proximal vein bundle is three-pronged, in contrast to the perpendicular insertion and consistently bifurcate veins characteristic of $P$. apicalis. Corsin also illustrates fertile material similar to Goeppert's holotype, in which elongate sori are developed along the length 
of the lateral veins; this contrasts with the rounded type of sori or synangia indicated in the present material of $P$. apicalis. While the distinction between the vegetative material identified by Knight (1985) as $P$. treviranii in the Sabero Coalfield and the material now identified as $P$. apicalis is necessarily subjective, given the range of material available for comparison, nevertheless it is apparent that the concept of $P$. treviranii, as described by Goeppert (1836) and later used by Corsin (1951), rules out confusion with this latter species. In the Sabero material attributed to $P$. treviranii in Knight 1985, pinna terminals are better individualised with a bluntly triangular terminal pinnule, in contrast to the commonly fused and tapering terminals of $P$. apicalis.

A further species identified by Corsin (1951) in the Sarre-Lorraine Coalfield and which offers some close comparison with the present material is $P$. punctata Corsin. This species offers some points of comparison in terms of the apparent frond organisation and slender ultimate pinnae with elongate, acute and lightly fused terminals. However, P. punctata has rather broader pinnules (according to Corsin the $1 / \mathrm{b}$ ratio is most commonly close to $2: 1$ ) which are more broadly rounded and does not show the closely packed slender, acuminate pinnules characteristic of the longer ultimate pinnae of $P$. apicalis. $P$. punctata shows a much more strongly marked, robust mid-vein extending along the greater length of each pinnule, and which is decurrent at its base. At the base of a pinnule the most proximal vein bundles are illustrated as three-pronged; this contrasts with the consistently perpendicularly inserted pinnules and once-bifurcate venation of $P$. apicalis. Corsin's illustrated material indicates the sporadic occurrence of twice-forked veins, while the venation pattern is more parallel, running straight to the margin, in contrast to the strongly curved pattern in P. apicalis. Corsin also stresses in his species the very thick pellicle which often remains as a carbonaceous layer over the pinnules and commonly masks the venation and gives a robust and vaulted appearance; this contrasts with the much thinner-limbed appearance and preservation of $P$. apicalis. It is worthy of note that $P$. punctata falls within the complex pecopterid group around Pecopteris saraefolia Bertrand, a species recognised at a number of locations of Asturian age in the Cantabrian area (Wagner \& Álvarez-Vázquez, 2010). Corsin acknowledged the close similarity and ventured that $P$. punctata may be a variety of $P$. saraefolia. His description of $P$. saraefolia (Corsin, 1951) also considered the close similarity with Pecopteris schaumberg-lippeana (Stur), admitting possible co-identity. More recently Wagner \& Álvarez-Vázquez (2016) have suggested that $P$. punctata is synonymous with $P$. schaumberg-lippeana, with the implication that the only material figured from northern Spain as P. punctata, from the Olloniego Formation, Asturias (in Wagner, 1971), should be reassigned to the former species. The material from Asturias can be readily distinguished from
P. apicalis on the same criteria as distinguish this species from Corsin's material of $P$. punctata.

Pecopteris raconensis Němejc has been recorded and illustrated from the Cantabrian successions of the GuardoValderrueda Coalfield by Wagner (1983). This species is characterised by robust, predominantly once-bifurcate venation, which provides a point of similarity. However, pinnules are generally larger and consistently broader (length $5-7 \mathrm{~mm} ; 1 / \mathrm{b}$ ratio ranging $2: 1$ to $2.5: 1$ ) and more rounded than those of $P$. apicalis. Also commonly in $P$. raconensis, at the base of pinnules the basal two venation bundles show twice-forked three and four-pronged veins and the mid-vein is also frequently clearly decurrent.

\section{DISCUSSION OF SYSTEMATIC RELATIONSHIPS}

A number of authors in recent decades have endeavoured to address the classification of pecopterid foliage of similar type to this species through the concept of whole-plant systematics (e.g., Zodrow, 1990; Cleal, 2015). However, this approach, when dealing with solely vegetative material, requires assumptions of conspecific linkage between a type of foliage and a type of fertile material. It is evident that significant confusion arises around the attribution of "whole plant" generic names to fossil foliage morphospecies known only from vegetative material. Cleal (2015) argues for a restricted use of the generic name Pecopteris, to be limited to species with Senftenbergialike sporangia, on the basis that this comprised the material (Filicites (Pecopteris) pennaeformis) designated by Brongniart (1822) as illustrative of his subgeneric division Pecopteris, which was subsequently raised to generic status by Sternberg (1825). However, while subsequently accepting Pecopteris as of generic status, Brongniart (1828) made clear his interpretation of this group as vegetative foliage in twice or three times pinnate fronds; fertile material was stated as generally unknown. Brongniart (1828) provided extensive illustration of Pecopteris species and foliage, corresponding to the general morphology since widely described as "pecopterid". This concept and usage of Brongniart (1828) and the use of Pecopteris as the formgenus for vegetative foliage for which no fertile organs can be demonstrated, are deeply ingrained in palaeobotanical literature. This is particularly so where the form-species is attributed biostratigraphic significance in contrast to studies of botanical and systematic affinities. In this context it is important to note that the recent analysis by Cleal (2015) offers no satisfactory generic name for vegetative pecopterid material without incorporating assumptions as to the fertile organs. For this reason, the generic name Pecopteris is retained for the material here described. 
The vegetative foliage of $P$. apicalis corresponds in many important characteristics, as summarised by Zodrow (1990), to a style of frond organisation and pinnule morphology widely recognised as characteristic of a broadly defined group of pecopterid form species, variously referred to as the "Pecopteris cyathoïdes" (Zeiller, 1900, p. 88), "les Pecopteris cyathéoïdes" (Bertrand, 1934), "groupe du Pecopteris arborescens" (Corsin, 1951), Cyatheae ("= groupe du $P$. cyathea ou des Pecopteris cyathéoïdes") (Corsin, 1955), or cyatheoids (Zodrow, 1990).

The broad term "Cyathoides" was introduced by Brongniart (1834) as a subgroup of Pecopteris, with the following brief diagnosis (original in Latin): "pinnules contiguous, arising more or less conjoined, thinner at the base, entire, rarely denticulate, with thin veins, arising obliquely from the mid-vein and forked or more rarely simple and separate". The description and illustration of the species included in this grouping makes clear that these are characterised by a bi- or tri-pinnate frond structure with relatively long, elongate pinnae bearing small rounded pinnules which are more or less perpendicularly inserted. However, this grouping also included species which may now be normally referred to various genera including Alethopteris Sternberg, Mariopteris Zeiller or Senftenbergia Corda, and also to a range of Mesozoic material, and it can be concluded that this early concept does not now contribute to an understanding of affinities in Pennsylvanian compression foliage.

Nevertheless, the concept of a "cyatheoid" group of Pecopteris morphospecies has persisted, particularly following the monographic work of Corsin (1951) on the pecopterids of the Sarre-Lorraine Coalfield, in which abundant vegetative foliage was assigned to eleven groups of morphospecies. Amongst these the "Groupe de Pecopteris arborescens" contained nine species, including three species (Pecopteris lepidorachis, P. cyathea and $P$. pectinata Bertrand) which were considered amongst the most closely comparable material at the time of original description (Knight, 1983, 1985) of P. apicalis. However, other comparable species had been assigned by Corsin to the "Groupe de Pecopteris saraefolia", which included $P$. densifolia and also to the "Groupe de Pecopteris saraepontana", which included $P$. treviranii. Laveine (1970a, b) made use of Corsin's concept of the "Groupe de Pecopteris arborescens" in a study of fertile material of Pecopteris species from the Nord-Pas-de-Calais and SarreLorraine coalfields. The material from species attributed to this "group" gave a consistently uniform palynoflora of monolete spores attributable to Laevigatosporites and Puncatosporites.

Zodrow (1990) undertook a wide-ranging historical assessment of the literature and inspection of type specimens in attempting to circumscribe a range of pecopterid form-species which would fall within the "group of Pecopteris arborescens", all of which correspond to the concept of the "cyatheoid grouping". Although no succinct diagnosis was established, fundamental diagnostic criteria were identified as i) tripinnate fronds with thick sturdy rachides of all orders, ii) penultimate pinna terminations which may be blunt and abruptly tapered or long and tapering, iii) rachides of all three orders are punctate and may be striate and iv) the fertile material is assignable to Scolecopteris Zenker. The present material corresponds in all respects except as regards a positive identification with fertile material bearing Scolecopteris. However, it is incongruous to incorporate diagnostic characters which are commonly identified in adpression material with a fertile organ genus defined on petrified material and which can be seldom confirmed except in petrefaction preservation; in adpression material Scolecopteris cannot be determined definitively and is almost certainly indistinguishable from material commonly ascribed to Asterotheca Presl. Zodrow also identified a number of negative characteristics which would exclude inclusion in his cyatheoid grouping, none of which are applicable to the material of $P$. apicalis. The frond models and venation diagrams illustrated by Zodrow for the cyatheoid grouping are entirely consistent with the range recognised here for $P$. apicalis. It is concluded that $P$. apicalis corresponds to the cyatheoid group of pecopterid species within the Marattiales, and it is only the absence of clearly identifiable fertile organs which constrain an assertion that $P$. apicalis may be considered within the cluster of species commonly referred to the "group of Pecopteris arborescens".

\section{DISCUSSION OF THE PALAEOECOLOGY OF PECOPTERIS APICALIS}

All confirmed records of $P$. apicalis to date are within coal-bearing successions and closely associated with coal seams. The large amount of material of $P$. apicalis was collected from disturbed overburden from surface mine extraction of the Seam III-IV complex of coals of the Calero Member in the Peragido Block (Zona de Peragido) close to the Corralón Fault as mapped and illustrated in Wagner \& Winkler Prins (1970). The corresponding stratigraphic succession for the Peragido-Vallejo collection site is presented on Figure 10, which illustrates the general stratigraphic column for the eastern end of the Barruelo Coalfield, redrawn from Wagner \& Winkler Prins (1985). The fertile specimen illustrated as Figures $8 \mathrm{a}-8 \mathrm{~b}$ was collected from an opencast working on Seam VII in the central part of the Barruelo Coalfield, at a relatively short interval below the stratigraphic horizon of the PeragidoVallejo material and close to the stratotype for the base of the Barruelian substage. 


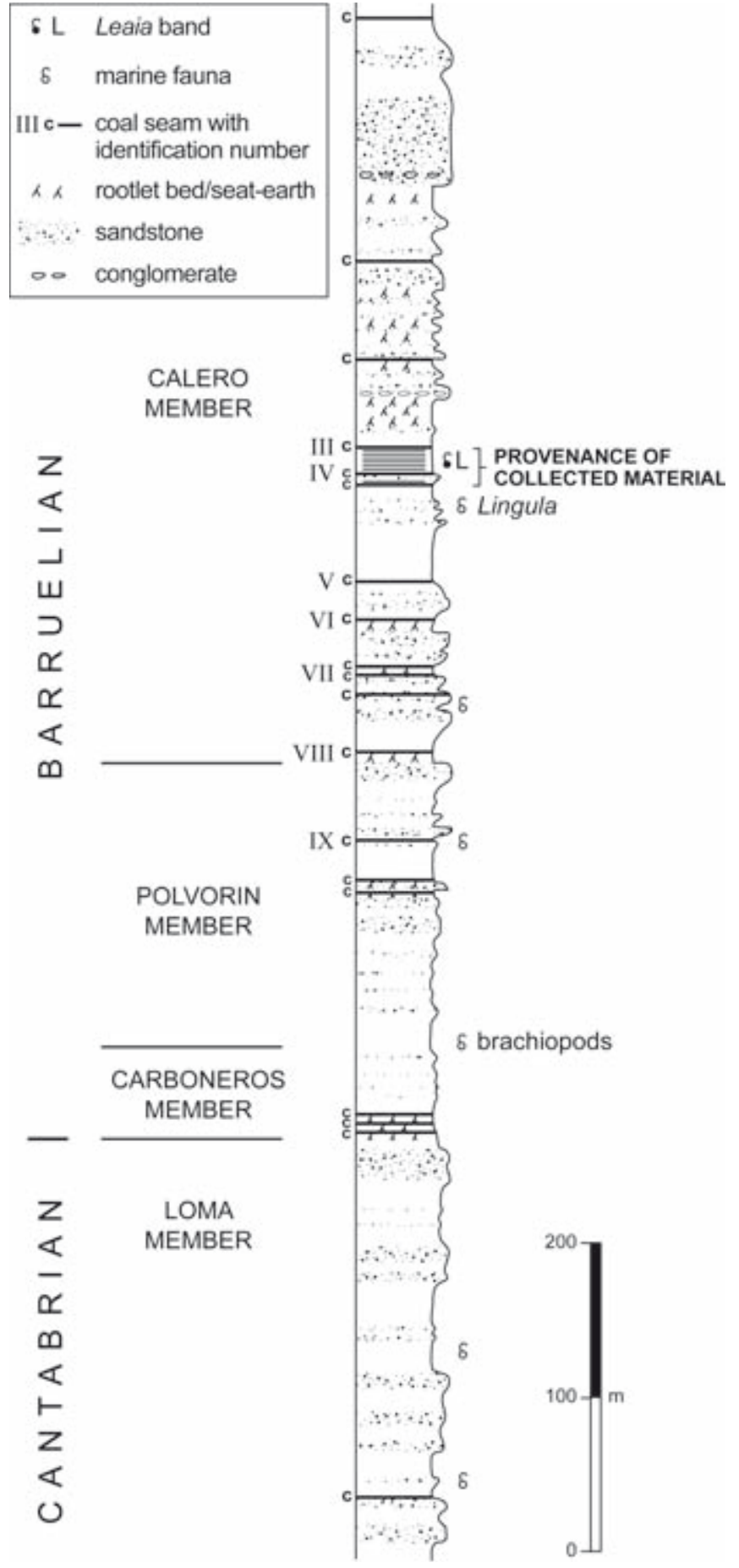

Figure 10. Stratigraphic column of the Barruelo Formation east of Pozo Peragido, Barruelo Coalfield, redrawn at scale 1:10,000, from columns published in Wagner \& Winkler Prins (1985).

The presence of unequivocal marine fauna within the lower Barruelian and Cantabrian succession of the Barruelo Coalfield confirms the sedimentary environment as situated on a coastal plain and at no significant distance from marine influence. The records from the younger coalfields deposited after the Asturian deformation, the
Sabero, Ciñera-Matallana and La Magdalena coalfields, are in successions with an identical coastal influence; Knight \& Wagner (2014) have documented similarly compelling evidence that the post-Asturian successions of the Cantabrian region lie in a similar coastal plain environment. It is therefore assumed that this species was an element of a flora which would be open to cosmopolitan influence and unconstrained across wide coastal areas around the Palaeo-Tethyan Sea; constraints on floral diversity would correspondingly be due to the local effects of the sedimentary environment.

The extensive Peragido-Vallejo collection provides information on the sedimentary environment of preservation and also on closely associated floral elements. Figures 11b-11c illustrate the large blocks from which the flora was collected. The sediment is consistently a dark grey silty mudstone, commonly with laminae of clearly discernible sand grade grains, occurring in a well laminated succession with some reddish iron oxidation apparently concentrated along slightly coarser horizons (Fig. 11b). Taking into account the interstratified widely lenticular sandstones of fluviatile character, the host sediments for the flora are identified as representing over-bank sediments in interdistributary areas of a coastal alluvial plain. This was a low energy environment in which large frond elements were preserved after very little transport from the site of growth. It is apparent from the illustrations of large frond elements (Figs 2a, 3b, 4a, 5a, 7a, 7c, 8a) that this preservation is characterised by the virtual absence of small comminuted plant debris, characteristic of higher energy sedimentation with corresponding degradation and transport of floated debris. Many large frond fragments are preserved or overlap on the same plane of sedimentation and successive layers with large frond fragments are commonly separated by only some 4-10 $\mathrm{mm}$ of sediment; no other sedimentary structures are apparent. It is concluded that the growth habitat was either entirely within a back-swamp environment frequently inundated by overbank flood events, or on immediately adjacent, slightly elevated, levees bounding fluvial channels.

The floral composition preserved in association with $P$. apicalis is very limited and monotonous. The frond material of $P$. apicalis is dominant on the planes of preservation but is accompanied by substantially complete pinnae of Neuropteris ovata Hoffmann (see Figs 4b, 8a) and Polymorphopteris polymorpha (Brongniart) Wagner (see Fig. 3b), although the fragments of these latter species are generally smaller in coverage of the bedding planes. A constant presence is also relatively long branches (30-100 $\mathrm{mm}$ ) of Asterophyllites equisetiformis (von Schlotheim) Brongniart (see Fig. 4a) and, less commonly, whorls of Annularia sp. (it has been suggested that this species is most probably A. spinulosa Sternberg, C. Álvarez-Vázquez pers. comm) (see Fig. 2a). No other floral elements have been recorded. In one large block, 

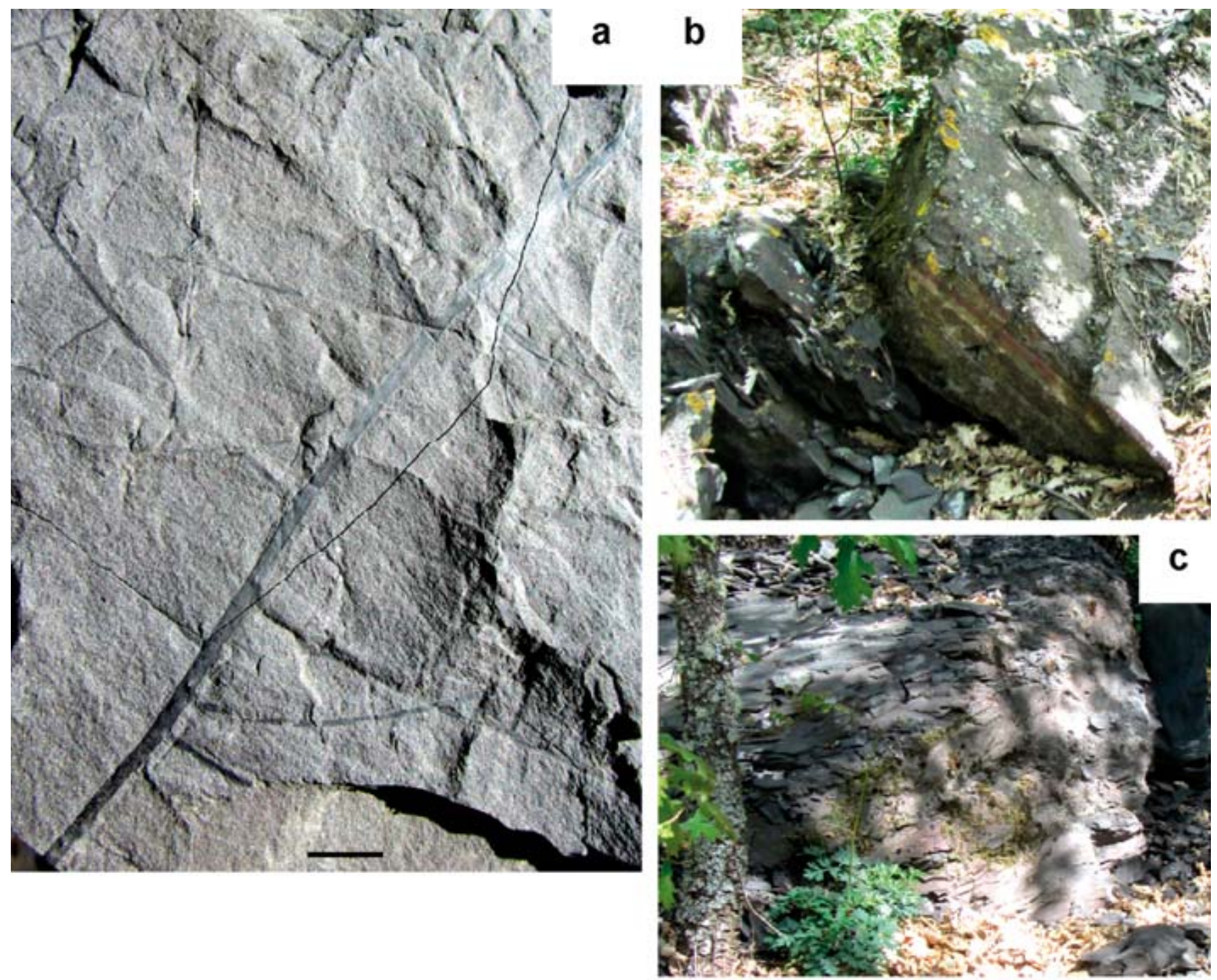

Figure 11. a) Smooth branching axes (x 1) in coarser silty mudstone at the Peragido-Vallejo collection site, interpreted as Pinnularia Lindley \& Hutton, a probable calamitacean root system. Scale bar $1 \mathrm{~cm}$. b) Large block of the material providing large slabs of preserved material at the Peragido-Vallejo collecting site. Block surface approximately $1 \mathrm{~m} \times 1 \mathrm{~m}$. c) Large block of silty mudstone at the Peragido-Vallejo collection site, in the process of being split and reduced to record flora. Block thickness approximately $0.8 \mathrm{~m}$.

representing a sedimentary thickness of over $1 \mathrm{~m}$, with slightly coarser silty bands between bedding planes with foliar elements, there is the common presence of smooth branching axes (Fig. 11a) here interpreted as Pinnularia Lindley \& Hutton, representing probable calamitacean roots. While it cannot be excluded that this type of root structure may also have been produced by pteridosperms, it is nevertheless suggestive that the back-swamp area was populated by more or less extensive stands of arborescent calamitaceans.

\section{CONCLUSIONS}

The large frond fragments of $P$. apicalis from the PeragidoVallejo collection site have provided a unique opportunity to document the morphological variation within a marattialean fern of cyatheoid affinities. P. apicalis, known previously from a large amount of relatively small fragments, only the holotype showing frond organisation above that of last order pinnae, is now documented with a clear record of frond organisation in antepenultimate pinnae, clearly indicative of a tripinnate frond structure. This record substantiates the consistent feature of oncebifurcate veins, other than in the terminal transition area of penultimate pinnae, the characteristic robust rachides 
with punctate and striate surface and also the rather variable terminals of pinnae of penultimate and perhaps antepenultimate order. Most commonly the terminals of penultimate order pinnae are relatively elongate and tapering, with an acuminate fused terminal area and relatively rapid transition between pinnules and the most distal last order pinnae. Nevertheless, some fragments illustrate that the transition between terminal pinnules and the uppermost last order pinnae can be more gradual with the development of long lobed pinnules, while in contrast the transition can sometimes be so rapid that the terminal area of penultimate order is blunt and truncated. However, the features of last order pinnae are very consistent, and although length of pinnae and the number of pinnules can be very variable, the parallel-sided shape, gradually tapering upper part of the pinna and the fused bluntly acuminate terminal are characteristic. The material from the Peragido-Vallejo site has not yielded unequivocal fertile material, but a well characterised specimen from a nearly equivalent horizon in the Barruelo Coalfield has provided evidence of fertile organs consisting of sori or synangia arranged in two series along either side of the pinnule midvein, in a manner reminiscent of Asterotheca, although the state of preservation permits no further precision. The difficulties implicit in attempting grouping of pecopterid species characterised primarily by vegetative features are well known; attempts to establish systematic divisions of pecopterid species have consistently required reference to, or assumptions on, the nature of the fertile organs. This has been discussed with respect to $P$. apicalis and it is concluded that closest affinities are with species attributed to the cyatheoid group of pecopterids (Zodrow, 1990) also referred to as the "group of Pecopteris arborescens" (Corsin, 1951). The preservation of the extensive material at the Peragido-Vallejo site suggests this species to be part of a flora of limited diversity, growing in or adjacent to a back-swamp area with periodic overbank inundation on an alluvial plain, situated at no great distance from the coast.

\section{ACKNOWLEDGEMENTS}

All the photographs of plant material accompanying this description have been taken by Mr Luis-José Sardina. Professor Robert Wagner made the first identification that the material described here should be identified with Pecopteris apicalis Knight. Mr Fernando Cuevas is thanked for making available the fertile specimen of $P$. apicalis collected from the opencast working on seam VII in the area of Barruelo Cemetery, and he, with other members of staff, is thanked for the support offered by the Museo Minero de Barruelo de Santullán for assisting the storage and care of fossil material. The authors express thanks to Dr Josef Pšenička for his assistance in revising this document, and thus contributing to a more comprehensive description and analysis of this material. Dra Carmen Álvarez-Vázquez is thanked for her help in the preparation of the figures in this work.

\section{REFERENCES}

Bertrand, P. 1934. Observations sur la classification des vrais Pecopteris. Comptes Rendus Académie des Sciences, Paris, CIC, 438-439.

Brongniart, A. 1822. Sur la classification et la distribution des végétaux fossiles en général, et sur ceux des terrains de sédiment supérieur en particulier. Mémoires du Muséum d'Histoire naturelle de Paris, 8, 203-348.

Brongniart, A. 1828. Prodrome d'une Histoire des Végétaux Fossiles. F.G. Levrault, Paris \& Strasbourg, 1-225.

Brongniart, A. 1834. Histoire des végétaux fossiles. Livraison 8 (janvier 1834), 289-312. Facsimile Edition W. Junk, Berlin (1915).

Castro-Martínez, M.P. 2005. La flora estefaniense B de La Magdalena (León, España), un referente europeo. Tomo I: Antecedentes y análisis florístico. Cuadernos del Museo Geominero, 4, 1-251.

Cleal, C.J. 2015. The generic taxonomy of Pennsylvanian age marattialean fern frond adpressions. Palaeontographica, Abt. B, 292, 1-21.

Corsin, P. 1951. Bassin houiller de la Sarre et de la Lorraine. I. Flore fossile, $4^{\mathrm{me}}$ fascicule. Pécoptéridées. Études des Gîtes Minéraux de la France, 177-370. Atlas, pls. CVIIICXCIX.

Corsin, P. 1955. Sur les Pecopteris et leur position systématique. Annales des Sciences Naturelles, Botanique, $11^{\mathrm{e}}$ série, XVI, 493-501.

Goeppert, H.R. 1836. Systema filicum fossilium. Verhandlungen der Kaiserlichen Leopoldinisch-Carolinischen Deutschen Akademie der Naturforscher, XVII (suppl.), 1- 486.

Knight, J.A. 1974. The Stephanian A-B flora and stratigraphy of the Sabero Coalfield (León, N.W. Spain). Compte Rendu $7^{e}$ Congrès International de Stratigraphie et Géologie du Carbonifère, Krefeld 1974, III, 283-315.

Knight, J.A. 1975. The systematic and stratigraphic aspects of the Stephanian flora of the Sabero Coalfield. PhD Thesis, Department of Geology, University of Sheffield (unpublished).

Knight, J.A. 1983. The stratigraphy of the Stephanian rocks of the Sabero Coalfield, León (NW. Spain) and an investigation of the fossil flora. Part I. The stratigraphy and general geology of the Sabero Coalfield. Palaeontographica, Abt. B, 187, 1-88.

Knight, J.A. 1985. The stratigraphy of the Stephanian rocks of the Sabero Coalfield, León (NW. Spain) and an investigation of the fossil flora. Part III. Systematic Palaeobotany; Pecopterids. Palaeontographica, Abt. B, 197, 1-80. 
Knight, J.A. \& Wagner, R.H. 2014. Proposal for the recognition of a Saberian Substage in the mid-Stephanian (West European chronostratigraphic scheme). Freiberger Forschungshefte, C.548, psf- Paläontologie, Stratigraphie, Fazies, 22, 179-195.

Laveine, J-P. 1970a. Note préliminaire sur les spores in situ de quelques pécoptéridinées houillères. Implications paéobotaniques et stratigraphiques. In: Colloque sur la Stratigraphie du Carbonifère (eds. Streel, M. \& Wagner, R.H.). Congrès et Colloques de l'Université de Liège, 55, 299-307.

Laveine, J-P. 1970b. Quelques pécoptéridinées houillères a la lumière de la palynologie (II). Implications paléobotaniques et stratigraphiques. Pollen et Spores, XII (2), 235-297.

Sternberg, K. von 1825. Versuch einer geognostischbotanischer Darstellung der Flora der Vorwelt. Leipzig. Band I: 4 (1825), 1-48, pls. XL-LIX, A-E.

Wagner, R.H. 1971. The Westphalian D floras of the Olloniego and Esperanza formations in the Central Asturian Coalfield. In: The Carboniferous of Northwest Spain Part II, Trabajos de Geología Facultad de Ciencias, Universidad de Oviedo, 4, 461-505.

Wagner, R.H. 1983. Late Westphalian D and early Cantabrian floras of the Guardo Coalfield. In: Geology and Palaeontology of the Guardo Coalfield (NE León - NW Palencia), Cantabrian Mts. Instituto Geológico y Minero de España, 57-91.

Wagner, R.H. 1984. Megafloral Zones of the Carboniferous. Compte Rendu $9^{e}$ Congrès International de Stratigraphie et Géologie du Carbonifère, Washington and ChampaignUrbana 1979, 2, 109-134.

Wagner, R.H. 1985. Pecopteris hispanica sp. nov., an upper Stephanian fern from the Ciñera-Matallana Coalfield, NW Spain. In: Papers on the Carboniferous of the Iberian Peninsula (Sedimentology, Stratigraphy, Palaeontology, Tectonics and Geochronology) (eds. Lemos de Sousa,
M.J. \& Wagner, R.H.). Anais da Faculdade de Ciências do Porto, Supplement to Vol. 64 (1983), 1-4.

Wagner, R.H. 2009. Geology of the Palaeozoic strata in northern Palencia. In: Present and future of Palaeobotany in Southwest Europe. $16^{\text {th }}$ International Congress OFP in honour of Robert H. Wagner, Aguilar de Campoo, September 2009, 49-69.

Wagner, R.H. \& Artieda, J.I. 1970. La Cuenca Minera CiñeraMatallana. Sociedad Anónima Hullera Vasco-Leonesa, León, 1-288.

Wagner, R.H. \& Álvarez-Vázquez, C. 2010. The Carboniferous floras of the Iberian Peninsula: A synthesis with geological connotations. Review of Palaeobotany and Palynology, 162 (3), 238-324; doi:10.1016/j.revpalbo.2010.06.005.

Wagner, R.H. \& Álvarez-Vázquez, C. 2016. A reappraisal of Pecopteris miltonii (Artis) Brongniart, a mid-Westphalian fern. Proceedings of the Yorkshire Geological Society, 61 (1); doi:10.114/pygs2015-368

Wagner, R.H. \& Winkler Prins, C.F. 1970. The stratigraphic succession, flora and fauna of Cantabrian and Stephanian A rocks at Barruelo (prov. Palencia), N.W. Spain. In: Colloque sur la Stratigraphie du Carbonifère (eds. Streel, M. \& Wagner, R.H.). Congrès et Colloques de l'Université de Liège, 55, 487-551.

Wagner, R.H. \& Winkler Prins, C.F. 1985. The Cantabrian and Barruelian stratotypes: a summary of basin development and biostratigraphic information. In: Papers on the Carboniferous of the Iberian Peninsula (Sedimentology, Stratigraphy, Palaeontology, Tectonics and Geochronology) (eds. Lemos de Sousa, M.J. \& Wagner, R.H.). Anais da Faculdade de Ciências do Porto, Supplement to Vol. 64 (1983), 359-410.

Zeiller, R. 1900. Éléments de Paléontologie. Paris, 1-421.

Zodrow, E. 1990. Revision and Emendation of Pecopteris arborescens group, Permo-Carboniferous. Palaeontographica, Abt. B, 217, 1-49. 